\section{ESTIMATION OF HYDROLOGICAL CHANGES IN A TROPICAL WATERSHED USING MULTI-TEMPORAL LAND-USE AND DYNAMIC MODELLING}

\author{
Al-Amin Danladi Belloa, Mohd Ridza Mohd Haniffaha,b*, Noor \\ Baharim Hashima, Khairul Mohammad Anuarc
}

aDepartment of Hydraulics and Hydrology, Faculty of Civil Engineering, Universiti Teknologi Malaysia, 81310 UTM Johor Bahru, Johor, Malaysia

${ }^{b}$ Centre for Coastal and Ocean Engineering, Research Institute for Sustainable Environment (RISE), 81310 UTM Johor Bahru, Johor, Malaysia

cNational Hydraulic Research Institute of Malaysia (NAHRIM), 43300 Seri Kembangan, Selangor, Malaysia
Article history

Received

12 June 2017

Received in revised form

19 November 2017

Accepted

15 January 2018

Published online

1 April 2018

*Corresponding author mridza@utm.my

\section{Graphical abstract}

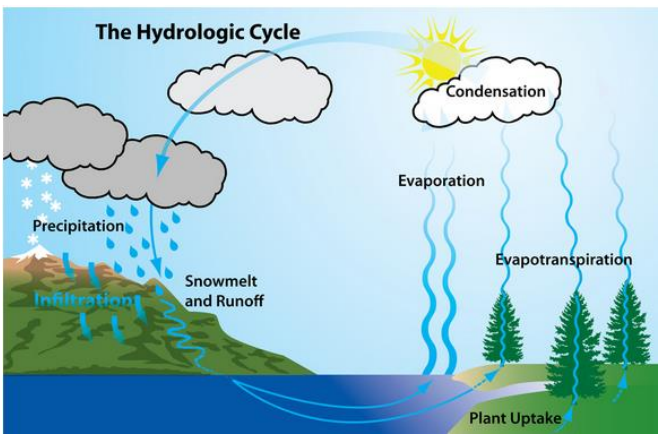

\begin{abstract}
The response of a watershed due to changes in its physical environment migh result in floods, river erosions and siltations, subsequently affecting humans and biotas. Evaluating land-use changes is crucial for better assessment of hydrological conditions in a watershed system. The remote sensing imagery, field data collection, and land change modelling were used to produce the land-use maps of different spatiotemporal scale from 1989 to 2039. The generated maps are integrated into Hydrological Simulation Program-Fortran (HSPF) model, to evaluate the hydrological changes in Skudai River watershed in Malaysia. Total runoff is expected to account for $57 \%$ of the rainfall influx by 2039 , a change of $2 \%$ from 1989 land-use, an indication of the low response of runoff to change in land-use. As built-up land increase by $3.39 \%$, the average streamflow will increase by $0.05 \mathrm{~m}^{3} / \mathrm{s}$. It will further reduce actual evapotranspiration (AET) by $0.39 \%$, groundwater by $0.34 \%$ and change in storage by $0.38 \%$. The sensitivity analysis of the hydrological elements to the land-use changes indicates that AET being the most sensitive then change in storage, and total runoff showing the lowest sensitivity. The result of the study provides information on the long-term impact of land-use on the hydrology of the tropical watershed, and it can be a useful tool in the planning and management of a watershed in a different perspective.
\end{abstract}

Keywords: Tropical-climate, dynamic model, Skudai River watershed, total runoff, actual evapotranspiration

\begin{abstract}
Abstrak
Respon sesebuah kawasan tadahan hujan kepada perubahan alam sekitar termasuklah yang boleh membawa kepada banjir, hakisan permukaan sungai dan enapan yang kemudian akan memberi kesan kepada manusia, flora dan fauna. Penilaian perubahan guna tanah adalah kritikal dalam memastikan keadaan hidrologi sesebuah kawasan tadahan dapat dikenalpasti dengan baik. Imej remote sensing, koleksi data padang dan permodelan perubahan tanah telah digunakan untuk menghasilkan peta guna tanah yang mempunyai variasi masa dan ruang untuk tahun 1989 sehingga 2039. Peta yang terhasil diintegrasikan ke dalam Hydrological Simulation Program-Fortran (HSPF) untuk menilai perubahan hidrologi kepada kawasan tadahan Sungai Skudai di Malaysia. Jumlah air larian permukaan
\end{abstract}


adalah dianggar merangkumi $57 \%$ daripada jumlah hujan menjelang tahun 2039, perubahan $2 \%$ daripada guna tanah tahun 1989. Ini menunjukkan respon yang rendah oleh air larian permukaan terhadap guna tanah. Purata kadaralir sungai akan meningkat $0.05 \mathrm{~m}^{3} / \mathrm{s}$ apabila tanah pembangunan bertambah sebanyak $3.39 \%$. Seterusnya, ini membawa kepada pengurangan evapotranspirasi sebenar (AET) sebanyak $0.39 \%$, air bumi sebanyak $0.34 \%$ dan perubahan penyimpanan air sebanyak $0.38 \%$. Analisis sensitiviti kepada elemen-elemen hidrologi terhadap perubahan guna tanah menunjukkan AET mempunyai sensitiviti yang tertinggi, diikuti penyimpanan air dan jumlah air larian permukaan. Keputusan kajian ini telah memberikan maklumat dan informasi kepada kesan jangka panjang guna tanah terhadap hidrologi kawasan tadahan beriklim tropikal dan seterusnya boleh diaplikasikan untuk tujuan perancangan dan pengurusan kawasan tadahan menggunakan perspektif yang baru.

Kata kunci: Iklim tropikal, Permodelan dinamik, kawasan tadahan Sungai Skudai, Air larian permukaam, evapotranspirasi sebenar

(C) 2018 Penerbit UTM Press. All rights reserved

\subsection{INTRODUCTION}

Prior studies have revealed that human activities and environmental changes alters the hydrological conditions of most watersheds [1]. An understanding of the nature and dynamics of a watershed involves the integration of the watershed land-use changes with its natural climate [2]. It was observed that changes in land-use affects the hydrology of a watershed [3], and these changes influence the quantity of the overland flow [4-6], water quality [7] and the natural hydrological cycle [8]. Also, it triggers frequent flash flood and even larger flood events especially in an abundant rainfall region like Malaysia, with negative consequences on both human and biota.

A lot of methodologies have been developed to evaluate the impact of land-use on the hydrology of a watershed. Among them are the idealized approach [9-11] and the used of spatial analysis [1113] However, an alternative method that integrates both GIS (using temporal data) and boundary conditions to model the hydrology of a watershed system shows a better and more practical result as demonstrated by Lin [14]. They utilized spatial data as an input to the Generalize Watershed Loading Function (GWLF)model to study the impact of landuse change in Wu-Tu Watershed. A Similar study also utilized Soil Water Assessment Tool (SWAT) model to investigate the response of the headwater hydrology due to land-use change [15] and streamflows [16]. However, integration of multi-temporal land-use maps of different timescales to estimate the hydrological variation of the watershed system is yet to be elucidated considering tropical climate condition. In this study, Hydrological Simulation Program-Fortran (HSPF) model and multi-temporal land-use are integrated to estimate the hydrological changes of a tropical watershed. The aim is to evaluate the impact of land-use changes on the hydrology of the Skudai River watershed using basinwide simulation.

\subsection{METHODOLOGY}

\subsection{Research Design}

The summarized methodology and steps taken to achieve the objective of this study is shown in Figure 1. Historical and projected land-use were produced using remote sensing techniques and land-change modeler (LCM). The generated temporal land-use were integrated into a GIS-based model to evaluate the impact of land-use changes on the hydrology of a tropical watershed. As shown in the methodology chart, each step was outlined and discussed in the subsequent sections.

\subsection{Study Area}

Skudai River watershed was selected for the study because it's a coastal watershed in a tropical climate, characterized with rapid urbanization, and coupled with the propose planned future development. The watershed was in Johor state, Malaysia (Figure 2) and it falls between 102 $59^{\prime} 54.19^{\prime \prime}$ $E$ and $104^{\circ} 11^{\prime} 8.54^{\prime \prime} E$ of longitude and 1 ${ }^{\circ} 56^{\prime} 31.67^{\prime \prime} \mathrm{N}$ and $1^{\circ} 22^{\prime} 41.16^{\prime \prime} \mathrm{N}$ of latitude, and measures $33.54 \mathrm{~km}$ in length and $16.29 \mathrm{~km}$ width, and covered the total area of $287.44 \mathrm{~km}^{2}$. The watershed is divided by its major rivers; the Sengkang River, Senai River, Melana River and Danga River. The Sengkang River is located at the upstream part of the watershed and is predominantly agricultural and rural settlement. Melana and Senai River are located at the middle of the watershed, and their catchments are dominated by urban and forest land. The downstream section of the watershed was also urbanized with little agriculture and forest land, and it falls within the Danga River catchment. Though, the entire length of the main river (Skudai River) was $47.4 \mathrm{~km}$ which flows from the western part of Johor (Sedenak) to the southern part (Johor Bahru) and discharges directly into Johor Strait. The climate is tropical rainforest with 


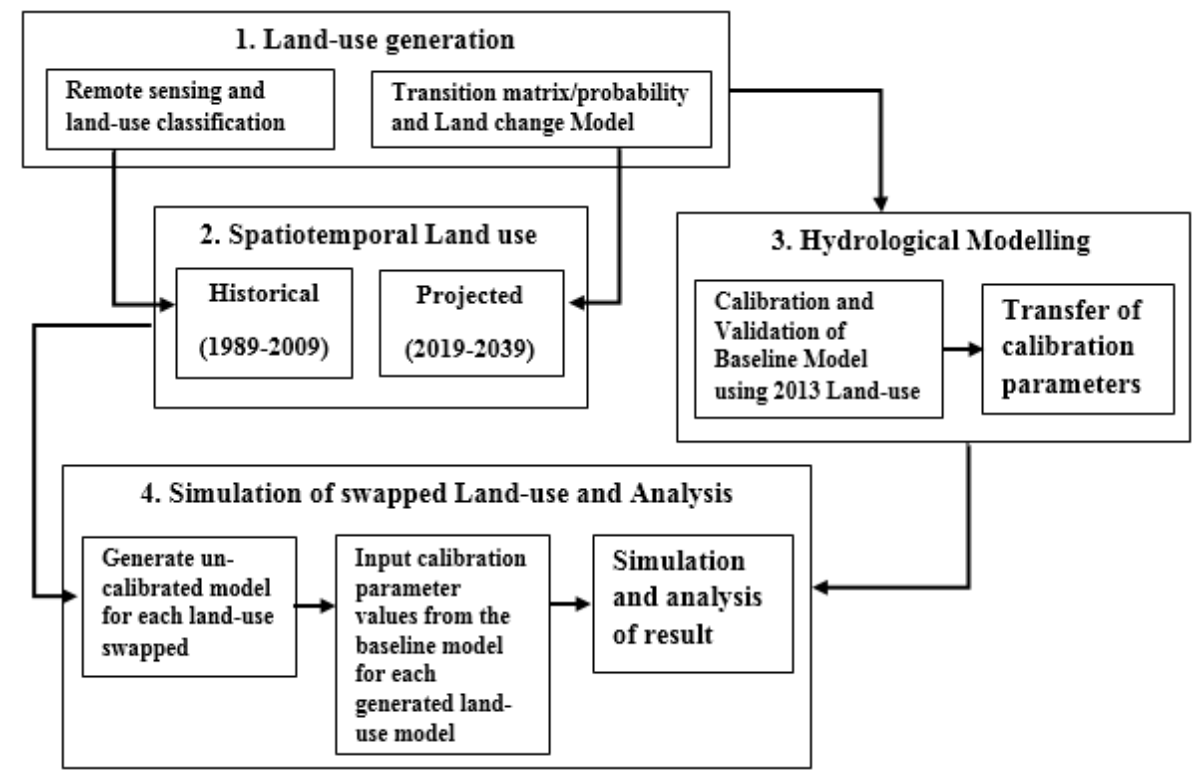

Figure 1 Summary of the methodology

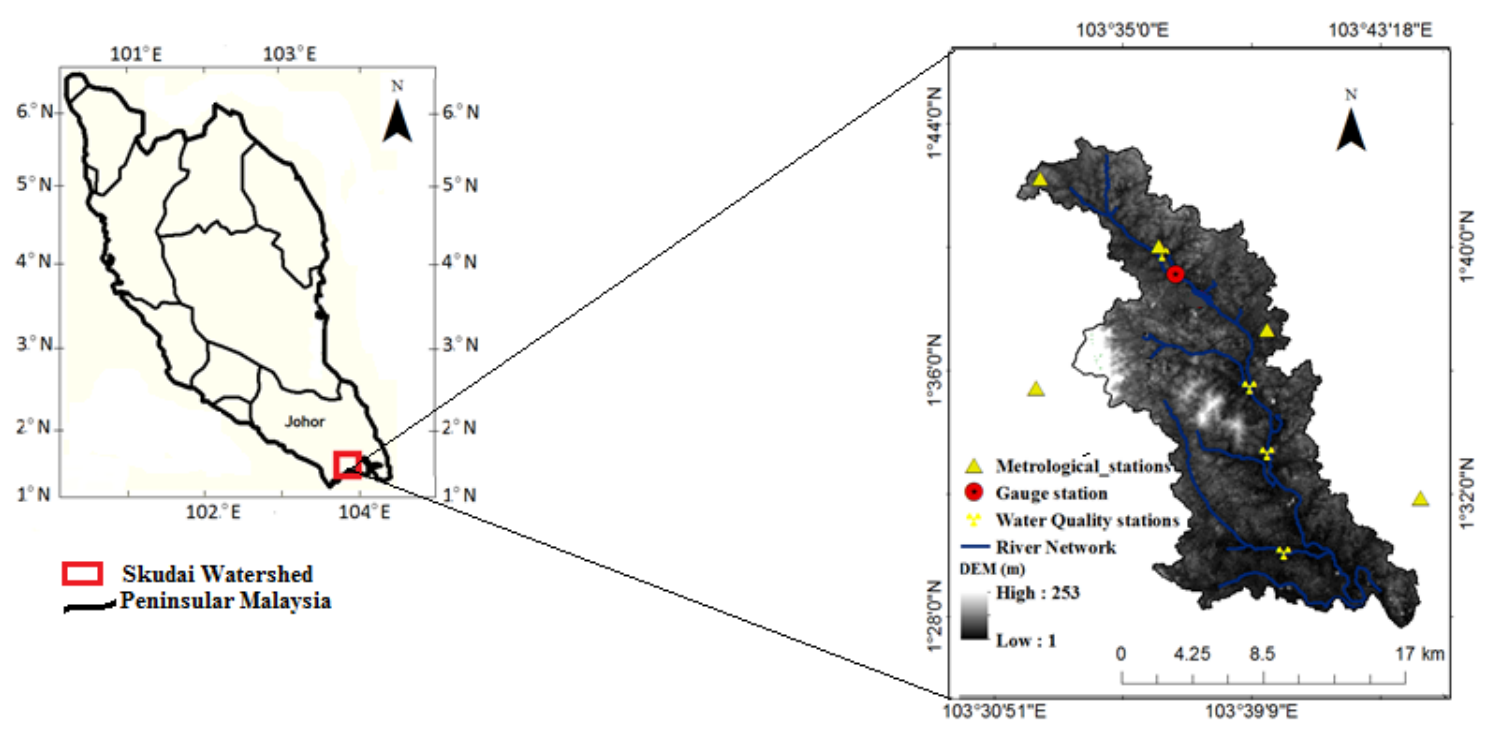

Figure 2 Location and characteristics of Skudai River Watershed

\subsection{Data Collection}

We summarized the input data used in this study (Table 1). A remote sensing data that covers the period of 1989, 1999, 2009, 2013 and 2015 were obtained from USGS EROS Data Centre (EDC) and access via USGS Global Visualization Viewer (GLOVIS). The imageries were captured by Landsat45. Landsat 7 of thematic mapper (TM) and enhanced thematic mapping $(E T M+)$ sensors respectively, at special resolutions of $30 \times 30 \mathrm{~m}$. We ensured that all the imageries obtained were within the seasonal variation of the study area. Though the imageries have varied quality and product; it was ensured that each of the images have the same pixel level, enhanced spatial resolution, textural and structural details utilizing the methodology adopted by Zheng [17]. Hourly precipitation records ranging from 6 to 29 years in the study area were obtained from the Department of Irrigation and Drainage of 
Malaysia (DID). Other meteorological data (dew temperature, cloud cover, solar radiation, evaporation and wind speed, and direction) were obtained from Malaysia Meteorological Department (MMD) and National Oceanic and Atmospheric Administration (NOAA) under National Centre for Environmental Information (access on the platform of Climate Data Online). The topographic data of $30 \mathrm{~m}$ resolution, 7.5-minute, one arc sec interval was acquired from Global data Explorer platform, and processed using ArcGIS. We utilized the refine topographic (DEM) data for the delineation of the watershed and characterization of the drainage areas. Local soil data was used for the study, obtained from soil survey division of Ministry of Agriculture and Fisheries.

Table 1 Data information used for the study

\begin{tabular}{|c|c|c|c|c|}
\hline Data type & Data name/Unit & $\begin{array}{l}\text { Period } \\
\text { cover }\end{array}$ & $\begin{array}{l}\text { Time } \\
\text { step/Resolution }\end{array}$ & Sources \\
\hline Meteorological & $\begin{array}{l}\text { Rainfall }(\mathrm{mm}) \text {, } \\
\text { temperature }\left({ }^{\circ} \mathrm{C}\right) \text {, wind } \\
\text { speed }(\mathrm{m} / \mathrm{s}) \text {, cloud } \\
\text { cover (Oktas), solar } \\
\text { radiation }\left(\mathrm{MJm}^{-2}\right) \text { and } \\
\text { evaporation }(\mathrm{mm})\end{array}$ & $1999-2015$ & hourly & $\begin{array}{l}\text { Department of irrigation and } \\
\text { drainage (DID), Malaysia } \\
\text { Meteorological department (MMD) } \\
\text { and NOAA climate data online }\end{array}$ \\
\hline Hydrological & Streamflow $\left(\mathrm{m}^{3} / \mathrm{s}\right)$ & $2002-2014$ & Monthly/hourly & $\begin{array}{l}\text { Universiti Teknologi Malaysia Data } \\
\text { collection and DID }\end{array}$ \\
\hline \multirow[t]{2}{*}{ Spatial } & $\begin{array}{l}\text { DEM (m) } \\
\text { land use }\end{array}$ & $\begin{array}{l}2010 \\
1989-2039\end{array}$ & $\begin{array}{l}30 \times 30 \mathrm{~m} \\
30 \times 30 \mathrm{~m}\end{array}$ & $\begin{array}{l}\text { USGS global data explorer } \\
\text { Generated using remote sensing }\end{array}$ \\
\hline & $\begin{array}{l}\text { Soil } \\
\text { Remote sensing } \\
\text { imagery }\end{array}$ & $\begin{array}{l}1970 \\
1989-2015\end{array}$ & $\begin{array}{l}1: 250,000 \\
30 \times 30 m\end{array}$ & $\begin{array}{l}\text { Ministry of Agriculture Malaysia } \\
\text { USGS global visualization data online }\end{array}$ \\
\hline
\end{tabular}

\subsection{Image Classification and Change Detection}

The remote sensing data obtained were processed using ArcGIS (v.10.3) software, these includes geometric correction, generation of the composite bond, supervised classification and accuracy assessment [18]. Each scene was geo-referenced on the Universal Mercator (UTM) projection at WGS 84 Datum, while the administrative map of the study area was superimposed on the Landsat composite imagery. We selected only those parts of the image that were within the watershed area for the image classification. A standard classification system was utilized in this study, because it gives a better picture of the watershed which provide a basis for the accurate analysis of the land-use. We adopt the supervised maximum likelihood land-use classification method as it was considered the most accepted procedure for land-use generation [19]. The accuracy of the results was measured using confusion matrix and kappa index, as this approach was defined as the best quantitative measurement of classification accuracy [20]. Land-use changes between the historical land-use datasets were evaluated using a multi-date post-classification comparison [21].

\subsection{Land Change Model}

A land change model (LCM) through IDRIS selva arcview was used for the temporal land-use modelling of the study area. The aim was to project the future land-use in accordance with the historical changes and planned urban development. LCM uses logistic regression or Multi-Layer Perceptron (MLP) neural network to predict future LU/LC changes. The 1989 and 2009 land-use maps were used as a basis for the future projection, while other constraints and factors were incorporated via multi criteria evaluation (MCE) technique. For more detailed procedures and further explanation read [22-23]. The projected land-use of the Skudai River watershed for the year 2019, 2029 and 2039 were produced from the validated the model (using 2015 land-use map).

\subsection{HSPF Model Description and Setup}

Hydrological Simulation Program FORTRAN (HSPF) is a semi-distributed model that divide a watershed into smaller sub-basin which in turn are treated as a single unit [24]. It simulates hydrologic and water quality processes on both pervious and impervious land surfaces and in streams. The model divides water movement into an overland flow, interflow, and groundwater flow [25]. It utilizes cell-based representation of the land segments, drainage system, and subdivided storage columns to characterize the flow of water and its availability for infiltration, runoff, and groundwater recharges. The model uses water balance concept to determine the distribution of the hydrological elements in the watershed system as shown in Equation 1.

$$
\Delta S=P-E T-Q-I N T-I N F
$$


Where $\Delta S$-change in storage, ET- evapotranspiration, Q-overland flow, INT- interception, INF-infiltration. HSPF model followed a routine simulation using the hydrological response units (HRUs) as delineated in the watershed, each HRU or sub-basin is simulated base on the land-use properties [26] (and this was essential for this study). In each sub-basin, the landuse is classified as either pervious lands (PERLND) or impervious lands (IMPLND) segments, assigned by each separate operation, this is to cover different storage zones and how there are interacted as related to water balance phenomenon [27], considering each segment.

Better Assessment Science Integrating Point and Nonpoint Sources (BASINS) program (v.4.1) was applied to integrate the physiographic information (topography, Land-use, and soil) of the watershed. A non-calibrated model for Skudai River watershed was produced through BASIN platform as a User Control Input file (UCl. File). The meteorological and other calibration input data were created using the WDMUtil program package which the HSPF model utilized as an external data source for simulation process. These input files are linked to HSPF model via a watershed data management file (. wdm) format that is unique to the Skudai River watershed study.

HSPF Expert System (HSPEXP+ 1.31) was used to support the calibration process [28]. The model was calibrated by parameter adjustment in accordance to the guidelines from USEPA technical note 6 [29-30]. Stream flows data were used for the calibration and validation process, and the calibration and validation period covered the period of 2002 to 2006 and 2008 to 2014 respectively. The data is at monthly time steps. A statistical criterion was also employed to evaluate the model performance. The coefficient of determination $\left(R^{2}\right)$, the Nash-Sutcliffe coefficient (NS), and PBIAS/Mean Percent Error are chosen for the model evaluation and their equations were illustrated below;

$$
\begin{gathered}
R^{2}=\left\{\frac{\Sigma\left(Q_{0}-\hat{Q}_{0}\right)\left(Q_{S}-\hat{Q}_{S}\right)}{\sqrt{\Sigma\left(Q_{S}-\hat{Q}_{S}\right)^{2}} \sqrt{\Sigma\left(Q_{0}-\hat{Q}_{0}\right)^{2}}}\right\}^{2} \\
\text { NS }=1-\frac{\Sigma\left(Q_{S}-Q_{0}\right)^{2}}{\Sigma\left(Q_{n}-\hat{Q}_{n}\right)^{2}} \\
\text { PBIAS }=\frac{\Sigma\left(Q_{0}-Q_{S}\right)}{\Sigma Q_{n}} \times 100
\end{gathered}
$$

Where $Q_{s}$ and $Q_{s}$ were the observed and simulated data, $\bar{Q}_{0}$ and $\bar{Q}_{s}$ were the mean observed and simulated data, $\mathrm{N}$ was the total number of data.

\subsection{Estimation of Hydrological Changes}

The Skudai River watershed hydrological model was produced using 2013 land-use as a baseline. We selected 2013 land-use as a baseline because it provides current information of the physical conditions of the watershed considering the simulation period from 2000 to 2015. The historical and future land-use of the watershed were swapped in each case and a new user control interface file (UCl. File) for each land-use map (from 1989-2039) was produced. However, the maps have equal time step (ten years interval) and covers the historical (1989. 1999 and 2009) and projected (2019, 2029 and 2039) land-use of the watershed. The calibration parameters obtained from the baseline model were maintained, and transferred to each land-use based model. We collected the computed water balance for each simulated land-use based model and analyzed. For consistency, in each swapped landuse simulated, the rainfall data and other meteorological data used for the baseline calibration were upheld. The estimation of the hydrological changes in the watershed were evaluated by detecting the variation of the water balance under each land-use using relative change and some statistical analysis. A spatial distribution of water yield at sub-basin scale were produced from the simulated mean annual water yield for each land-use swapped. We used the nearest neighbor interpolation technique to generate the spatial distribution of the water yield in the watershed [31]. The relative sensitivity of the hydrological components to land-use variation were measured using the relationship illustrated in Equation (5).

$$
\frac{\left|x_{i}-x_{b}\right|}{x_{b}}
$$

where $X_{i}=$ hydrological result of simulated land-use dataset used, the subscript $i$ denotes the year of land-use considered in the model run. $X_{b}=$ is the reference land-use hydrological simulation result, the subscript $b$ denotes the year of referenced land-use.

For this study, the reference land-use was the 1989 land-use, because it was assumed that the natural physiography of the watershed does not change much compared to the other land-use maps. 
Table 2 Classification Accuracy assessment using confusion matrix for each land-use/land-cover (LU/LC) datasets

\begin{tabular}{|c|c|c|c|c|c|c|c|c|c|c|}
\hline \multirow{3}{*}{$\begin{array}{l}\text { Land-use Class } \\
\text { Agricultural } \\
\text { land }\end{array}$} & \multirow{2}{*}{\multicolumn{2}{|c|}{$\begin{array}{l}1989 \\
\text { Accuracy/Kappa } \\
\text { index }\end{array}$}} & \multirow{2}{*}{\multicolumn{2}{|c|}{$\begin{array}{l}1999 \\
\text { Accuracy } \\
\text { Kappa Index }\end{array}$}} & \multirow{2}{*}{\multicolumn{2}{|c|}{$\begin{array}{l}2009 \\
\text { Accuracy/ } \\
\text { Kappa index }\end{array}$}} & \multirow{2}{*}{\multicolumn{2}{|c|}{$\begin{array}{l}2013 \\
\text { Accuracy/ } \\
\text { Kappa index }\end{array}$}} & \multirow{2}{*}{\multicolumn{2}{|c|}{$\begin{array}{l}2015 \\
\text { Accuracy/ } \\
\text { Kappa index }\end{array}$}} \\
\hline & & & & & & & & & & \\
\hline & 88.6 & 95.1 & 95.0 & 100.0 & 96.0 & 90.6 & 94.0 & 94.0 & 97 & 93.0 \\
\hline $\begin{array}{l}\text { Barren land } \\
\text { Built-up land } \\
\text { Forest land } \\
\text { Water/Wetland }\end{array}$ & $\begin{array}{l}93.6 \\
100.0 \\
73.9 \\
100.0 \\
\end{array}$ & $\begin{array}{l}97.5 \\
86.0 \\
85.0 \\
88.9 \\
\end{array}$ & $\begin{array}{l}92.5 \\
97.5 \\
96.7 \\
90.0 \\
\end{array}$ & $\begin{array}{l}92.5 \\
90.7 \\
100.0 \\
90.0 \\
\end{array}$ & $\begin{array}{l}88.0 \\
92.0 \\
92.0 \\
94.0\end{array}$ & $\begin{array}{l}89.1 \\
90.2 \\
97.8 \\
94.0\end{array}$ & $\begin{array}{l}90.0 \\
98.0 \\
96.0 \\
92.0 \\
\end{array}$ & $\begin{array}{l}90.0 \\
89.1 \\
97.9 \\
100.0 \\
\end{array}$ & $\begin{array}{l}91 \\
94 \\
92 \\
94\end{array}$ & $\begin{array}{l}89.0 \\
91.1 \\
96.7 \\
98.3 \\
\end{array}$ \\
\hline $\begin{array}{l}\text { Overall } \\
\text { Accuracy } \\
\text { Kappa } \\
\text { Coefficient }\end{array}$ & 90.7 & & 95.0 & & 92.4 & & 94.0 & & 93.2 & \\
\hline
\end{tabular}

\subsection{RESULTS AND DISCUSSION}

\subsection{Land-use Classification Accuracy}

In Skudai River watershed, five land-use classes (urban, agriculture, forest, wetlands, and barren) were adopted considering the physical conditions of watershed. The supervised maximum likelihood method was used for the land-use classification using training samples to generate the land-use classes from 160 control points of known land-use class. These control points were obtained from the Johor state base map, field survey, and navigation of the Google Earth software. The land-use of Skudai watershed for the years 1989, 1999, 2009, 2013 and 2015 were produced. The results of land-use classification accuracy were analyzed using confusion matrix and kappa index. The result shows an effective classification as illustrated by LU and Weng [32] and Coulter et al. [33]. The results of the accuracy assessment were shown in Table 2. Finally, the historical land-use of the study area were produced as shown in Figure 3(a-c). (a)

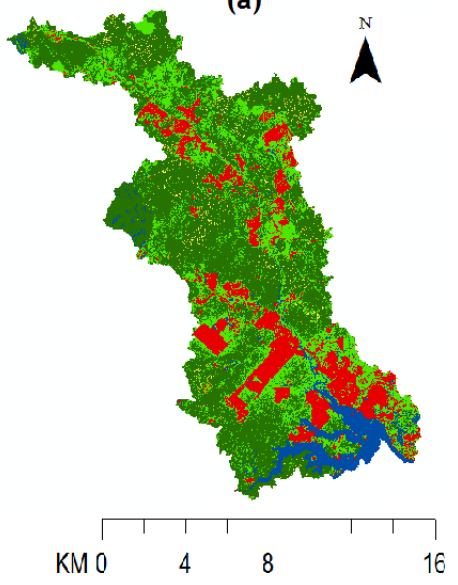

(b)

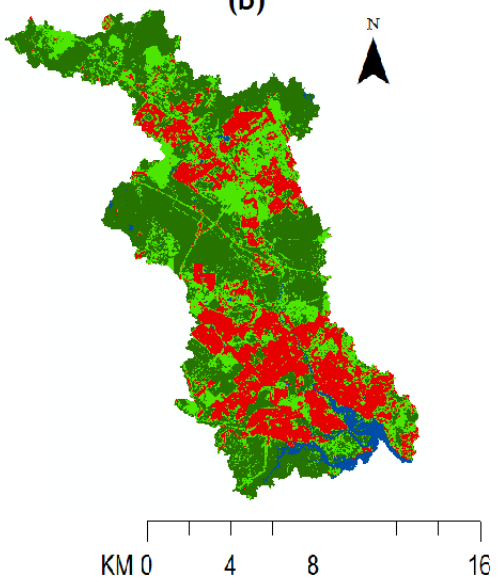

(c)

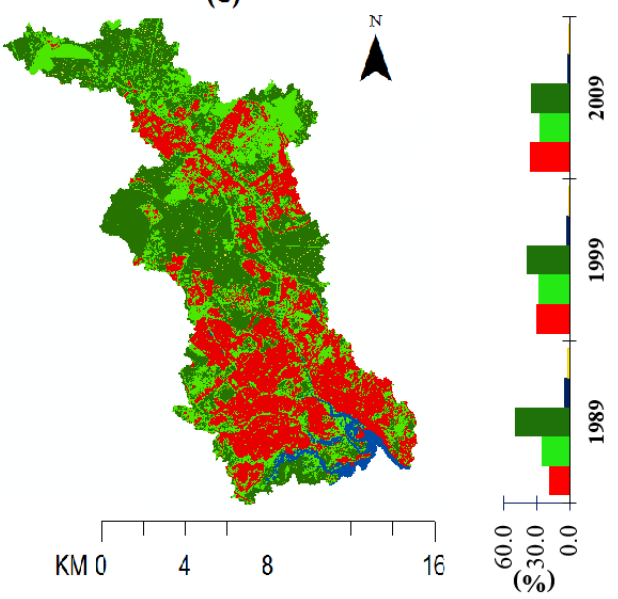

Built-up land Agricultural land $\square$ Forest land

\section{Barren land}

Figure 3 Historical land-use of Skudai River watershed (a)1989 (b) 1999 (c)2009

\subsection{Multi-temporal Land-use and Change Detection}

We generate the transition probability matrix using the Land Change Modeler (LCM) via IDRISI selva Arcview, utilizing the techniques demonstrated by Camacho [34], from the land-use of the year 1989 to 2009. The result indicates that urban areas are resistance to change (0.988), compared to forest land (0.4356) and wetland (0.5123) that shows susceptibility to changes. While agricultural land (0.7914) also, shows low susceptibility to change when compared with forest and wetland. Also, the generated transition matrix was used to predict the land-use of the year 2015, and validated with the corresponding observed land-use produced from the remote sensing data. The validation process in LCM 
uses cross-tabulation method to check the model performance [35], and the result shows $92 \%$ similarities and $8 \%$ variance. The validated model was then used to predict 2019, 2029, and 2039 land-use of the Skudai River watershed as illustrated in Figure 4(ac). A multi-date post-classification comparison between the historical and predicted land-use shows a significant change in the land-use class [36]. Builtup areas increased from $18.2 \%$ in 1989 to $36 \%$ in 2009 and it is projected to further increase to $49.2 \%$ by 2039. But forest land shows a decrease of $28.19 \%$ from 1989 to 2039 while agricultural land showed a slight decline with $25.7 \%$ total area in 1989 to $27.4 \%$ in 2009. It was projected that by 2039 agricultural land will reduce to $27.2 \%$. Wetland and barren land continue to reduce throughout the years. Table 3, detailed the changed detection observed between the land-use datasets over years froml1989 to 2039.

Table 3 Land-use characteristics and change detection

\begin{tabular}{lllllll}
\hline \multirow{2}{*}{ Land-use class (\%) } & \multicolumn{3}{l}{ Historical land use change } & \multicolumn{3}{l}{ Predicted land use change } \\
\cline { 2 - 7 } & $\mathbf{1 9 8 9}$ & $\mathbf{1 9 9 9}$ & $\mathbf{2 0 0 9}$ & $\mathbf{2 0 1 9}$ & $\mathbf{2 0 2 9}$ & $\mathbf{2 0 3 9}$ \\
\hline Built-up Area & 18.24 & 30.54 & 36.00 & 40.22 & 45.79 & 49.23 \\
Agriculture land & 25.66 & 28.22 & 27.44 & 29.45 & 28.28 & 27.27 \\
Forest land & 50.30 & 39.15 & 34.75 & 28.46 & 24.36 & 22.11 \\
Water/wetland & 4.61 & 2.07 & 1.44 & 1.03 & 0.92 & 0.81 \\
Barren land & 1.19 & 0.02 & 0.36 & 0.84 & 0.65 & 0.58 \\
\hline
\end{tabular}

(a)

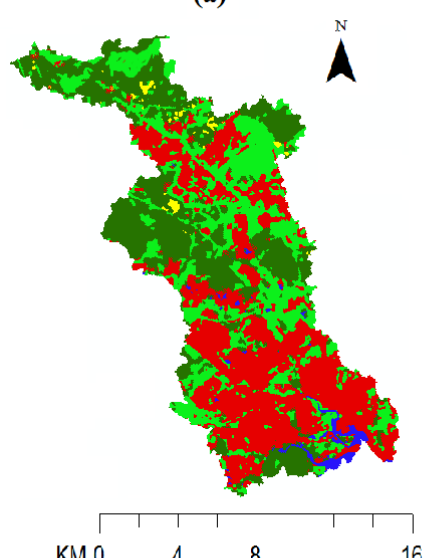

(b)

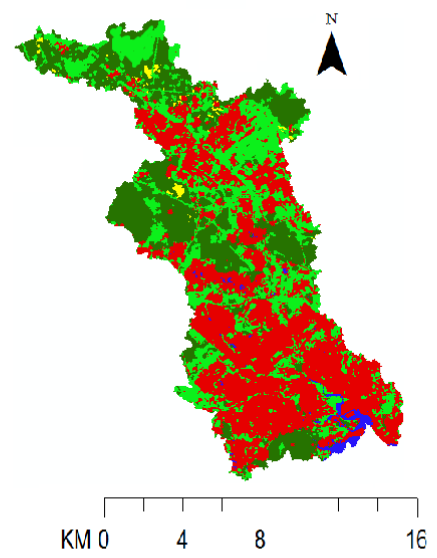

(c)

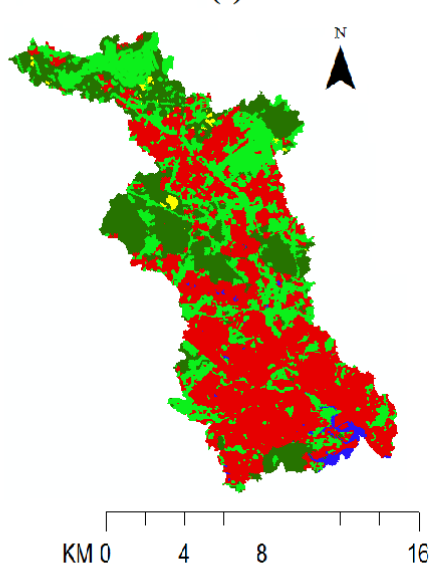

Water/Wetland

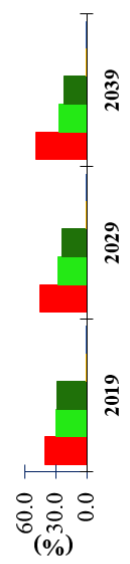

Barren land

Figure 4 Future land-use of Skudai River watershed (a)2019 (b)2029 (c)2039

\subsection{Evaluation of Model Performance}

Hydrological model of Skudai River watershed was produced using HSPF model. The model was calibrated using the observed streamflow data from the year 2002 to 2006 and validated from year 2008 to 2014. From the sensitivity analysis of the calibration parameters, it was observed that five parameters were more sensitive to calibration process. These parameters were; Fraction of $\mathrm{GW}$ inflow to deep recharge (DEEPFR), Lower zone nominal soil moisture storage (LZSN), Index to infiltration capacity (INFILT), Upper zone nominal soil moisture storage (UZSN), and Base groundwater recession (AGWRC). The model statistical performance check shows a good calibration and validation result [37]. Table 4 shows the accuracy assessment of the model calibration and validation result. The coefficient of determination indicates that the model describes $89 \%$ of the total variability in the observed data onto monthly flow level. The model performance is good at $11 \%$ underestimation of flow for six-years simulation period. The validation result shows that the model captured $83 \%$ variability of flow in the watershed and underestimation of $17 \%$ over six-year simulation period. Graphical model result for calibration and validation of the model are shown in Figure 5(a-b) and Figure 6(a-b) respectively. Comparison of the simulated monthly streamflows for the calibration and validation period shows that the peak streamflow for the calibration period is $5.9 \mathrm{~m}^{3} / \mathrm{s}$ and for the validation period is $3.8 \mathrm{~m}^{3} / \mathrm{s}$, which shows that the calibration peak flow is $2.1 \mathrm{~m}^{3} / \mathrm{s}$ higher than the validation peak flow. 
Table 4 Summary of HSPF model accuracy assessment for Streamflow prediction

\begin{tabular}{lll}
\hline \multirow{2}{*}{ Efficiency criteria } & \multicolumn{2}{c}{ Monthly } \\
\cline { 2 - 3 } & Calibration & Validation \\
\hline R $^{2}$ & 0.89 & 0.83 \\
NS & 0.88 & 0.82 \\
PBIAS (\%) & -6.28 & -3.91 \\
\hline
\end{tabular}

The minimum flow for validation period was $0.14 \mathrm{~m}^{3} / \mathrm{s}$ lower than that of calibration which shows that it was measured under different flow conditions [38]. The model result shows that even under different flow condition, the model was able to capture the variability of the streamflows in the Skudai River watershed.

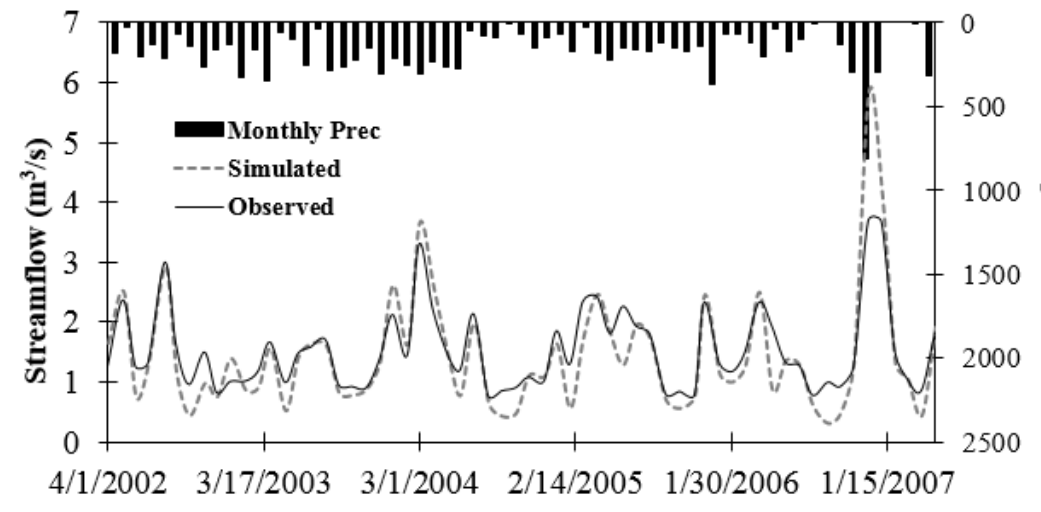

(a)

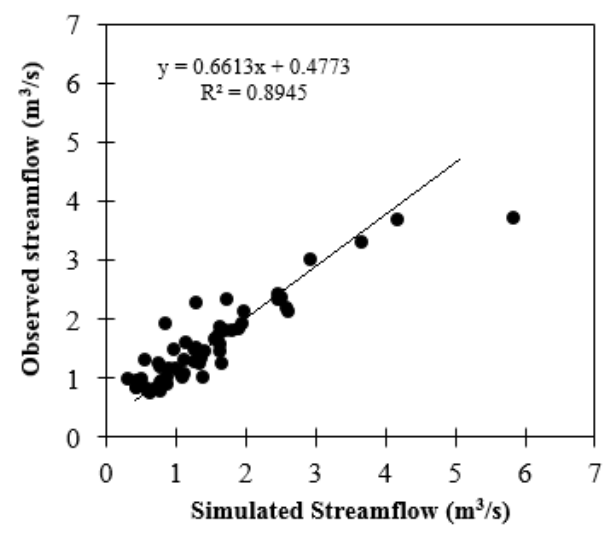

(b)

Figure 5 Calibration (a) Observed and Simulated Monthly streamflow (b) 1:1 scatter plot

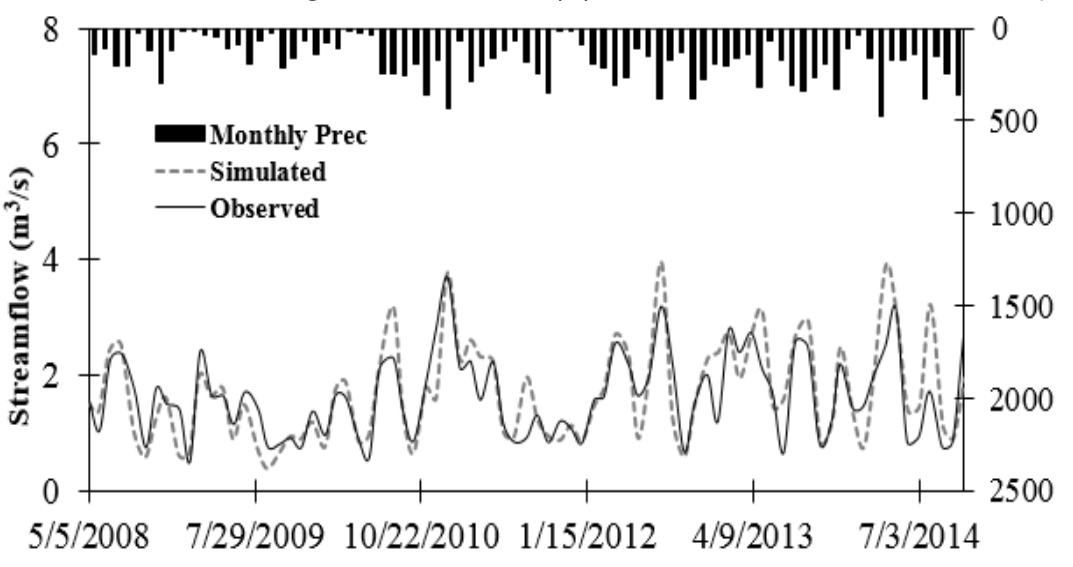

(a)

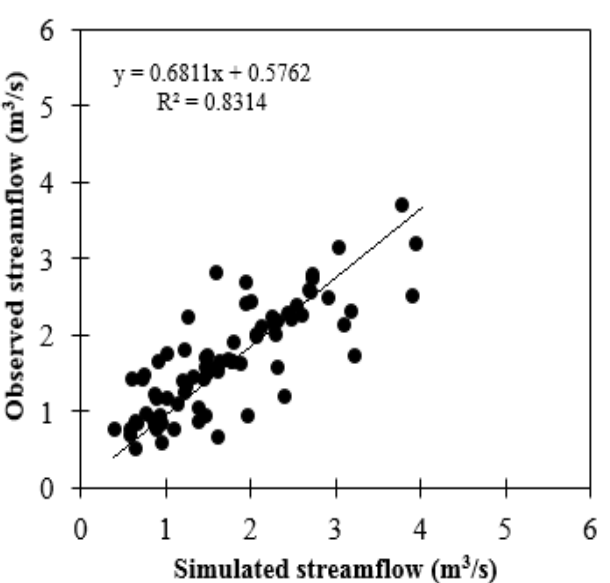

(b)

Figure 6 Validation(a)Observed and Simulated Monthly streamflow (b) 1:1 scatter plot

\subsection{Calibration Parameter Assessment}

Important calibration parameters were evaluated and compared with the Skudai River watershed geomorphological properties. The aim is to analyze how the model was able to characterize the watershed by the calibration parameters. The final calibration parameter values for each land-use class were shown in Table 5. The LZSN parameter is a conceptual parameter and it does not give hydrological meaning from the calibration value [26]. But index to lower zone evapotranspiration (LZETP) parameter value shows a variability among the landuse class, and It indicates the tendency for actual evapotranspiration at the lower zone. The values of the parameter show that wetland has more potential to evapotranspiration than forest, agriculture, built-up and barren land [27]. Parameter that defines the infiltration rate (INFILT) of a soil in the watershed, has a calibration value of $9.56 \mathrm{~mm} / \mathrm{h}$. This value falls within group $B$ classes defined by the hydrologic soil grouping (2.5-10.0 mm/h). The group class name corresponds to the Malaysia soil classification, as the soils in the watershed have moderate to rapid permeability [39]. However, the general soil texture varies; from fine-grained soils to acid sulphate soils [40]. Furthermore, the interflow inflow parameter (INTFW) has a value of 4.772, an indication for moderate percolation of water into the soil [26]. This value corresponds to the soil textural class which 
shows that the soil contains 78 to $81.2 \%$ sand, 16.7 to $20 \%$ clay, and 2 to $2.1 \%$ silt materials. But the influence of the dominant sand particle allow water to flow between soil pores and permit more of subsurface flow than overland flow [40].

Table 5 Values of calibrated parameters of Skudai Watershed Hydrology

\begin{tabular}{|c|c|c|c|c|c|c|}
\hline $\begin{array}{l}\text { Calibration } \\
\text { Parameter } \\
\text { (unit) }\end{array}$ & Definition of terms & $\begin{array}{l}\text { Agricultur } \\
\text { al land }\end{array}$ & $\begin{array}{l}\text { Barren } \\
\text { land }\end{array}$ & $\begin{array}{l}\text { Forest } \\
\text { land }\end{array}$ & $\begin{array}{l}\text { Built-up } \\
\text { land }\end{array}$ & $\begin{array}{l}\text { Wetlan } \\
\text { d }\end{array}$ \\
\hline AGWRC & Base groundwater recession & 0.8799 & 0.8799 & 0.8799 & 0.8799 & 0.8799 \\
\hline AGWETP & Fraction of remaining ET from active GW & 0.0200 & 0.0200 & 0.0200 & 0.0200 & 0.0200 \\
\hline BASETP & Fraction of remaining ET from baseflow & 0.0175 & 0.0299 & 0.0267 & 0.0133 & 0.0221 \\
\hline CEPSC (mm) & Interception storage capacity & 6.0900 & 2.5400 & 6.3500 & 2.5400 & 0.7600 \\
\hline DEEPFR & Fraction of GW inflow to deep recharge & 0.2988 & 0.2988 & 0.2988 & 0.2988 & 0.2988 \\
\hline INFILT (mm/hr) & Index to infiltration capacity & 9.5600 & 9.5600 & 9.5600 & 9.5600 & 9.5600 \\
\hline INTFW & Interflow inflow parameter & 4.772 & 4.772 & 4.772 & 4.772 & 4.772 \\
\hline IRC & Interflow recession parameter & 0.7880 & 0.7880 & 0.7880 & 0.7880 & 0.7880 \\
\hline KVARY $(1 / \mathrm{mm})$ & Variable groundwater (GW) recession & 95.9100 & 95.9100 & 95.9100 & 95.9100 & 95.9100 \\
\hline LZETP & $\begin{array}{l}\text { Lower zone evapo-transpiration (ET) } \\
\text { parameter }\end{array}$ & 0.6800 & 0.1500 & 0.7600 & 0.3900 & 0.8800 \\
\hline LZSN (mm) & Lower zone nominal soil moisture storage & 319.7600 & 319.7600 & 319.7600 & $\begin{array}{c}319.760 \\
0\end{array}$ & $\begin{array}{c}319.760 \\
0\end{array}$ \\
\hline NSUR & Manning's roughness for overland flow & 0.4500 & 0.4300 & 0.4400 & 0.4100 & 0.2800 \\
\hline UZSN (mm) & Upper zone nominal soil moisture storage & 40.0800 & 40.0800 & 40.0800 & 40.0800 & 40.0800 \\
\hline
\end{tabular}

\subsection{Influence of Land-use on the Water Balance}

The change in land-use influences the variation of the hydrological element such as overland flow, baseflow, interflow, change in storage etc. in the Skudai River watershed. Table 6, illustrates the variability of the hydrological components over the years as the land-use changes. The cumulative rainfall influx decreases at an average of $0.19 \times 10^{7} \mathrm{~m}^{3}$ per annum as urban built-up increase by $7.3 \%$ per annum. Also, surface runoff increases by $6 \%$ while baseflow and interflow were expected to decrease by $19.9 \%$ and $19.8 \%$ respectively, between the period of 1989 and 2039. This change is due to increase in built-up areas from $18.2 \%$ to $49.2 \%$ within the period of 1989 and 2039 which result in the reduction of baseflow and interflow and increased surface runoff. Our findings correspond with prior studies that evaluate the impact of land-use on the flow condition of a watershed considering similar climatic conditions [41-43]. The total runoff in the watershed varied from $55 \%$ in 1989 to $57 \%$ in 2039 . It shows an increase of $2 \%$ over the years, an indication of low response of the watershed to total runoff as the landuse changes. This is because the soil type, and the undulating terrain that exists in the forest and agricultural lands, combine with the surface runoff coming from the built-up areas promote total runoff (especially baseflow and overland flow) to contribute more to water loss.

Table 6 Average Annual Hydrological budget of Skudai watershed as LU/LC changes (simulation period Jan, 2000 to Jul, 2015)

\begin{tabular}{llllllll}
\hline \multirow{2}{*}{ Element } & \multirow{2}{*}{ Constituents } & \multicolumn{7}{c}{ Volume $\mathbf{x ~ 1 0 ^ { 7 } ( \mathbf { m } ^ { 3 } )}$} \\
\cline { 3 - 8 } & & 1989 & 1999 & 2009 & 2019 & 2029 & 2039 \\
\hline Rainfall & & 65.38 & 63.82 & 60.27 & 55.74 & 55.39 & 55.39 \\
\hline Runoff & Overland & 10.78 & 11.14 & 11.10 & 11.06 & 11.06 & 11.43 \\
& Interflow & 8.09 & 7.79 & 7.25 & 6.58 & 6.54 & 6.48 \\
& Baseflow & 17.07 & 16.45 & 15.34 & 13.92 & 13.81 & 13.68 \\
\hline Actual- & Interception & 6.18 & 5.97 & 5.57 & 5.06 & 5.02 & 4.97 \\
Evapotranspiration & Upper zone & 5.05 & 4.86 & 4.54 & 4.10 & 4.07 & 4.03 \\
& Lower zone & 9.25 & 8.92 & 8.33 & 7.54 & 7.48 & 7.41 \\
\hline
\end{tabular}




\begin{tabular}{llllllll}
\hline & Groundwater & 0.51 & 0.49 & 0.46 & 0.42 & 0.41 & 0.41 \\
& Baseflow & 0.17 & 0.16 & 0.15 & 0.14 & 0.14 & 0.14 \\
\hline Deep Groundwater & & 7.60 & 7.38 & 6.94 & 6.37 & 6.32 & 6.30 \\
\hline Change in Storage & & 0.67 & 0.65 & 0.60 & 0.55 & 0.54 & 0.54 \\
\hline
\end{tabular}

Actual evapotranspiration (AET) due to interception (from forest, agricultural and urban areas), at the lower and upper zone, at the baseflow and groundwater shows a decrease with increased built-up areas. Maintaining the same trend as observed on the baseflow and interflow runoff. But at the lower zone, the AET loss is higher compared to the others, and contributes more to total AET loss in the watershed, followed by interception and upper zone AET losses. The reason for the higher AET loss at the lower zone is due to the soil hydrological property that allow more of infiltration and percolation of water than surface runoff. Although there is an increase in impervious land areas, but Interception contribute less to total AET loss when compared to lower zone. However, interception is considered the second sources of AET loss in the watershed, because of the high vegetative cover due to abundant rainfall (in forest land) and the nature of agricultural practices in the watershed (mostly plantations farms). As Tang et al. [44] shows that ET loss depends on the density of the vegetation cover and their location within a watershed. They illustrate that ET loss is higher at the hilltop than at the valley, and this implies that the ET loss in Skudai River watershed is influence by the vegetation cover and the climatic condition of constant high temperatures [45]. Also, the deep groundwater in the watershed decreases from $7.6 \mathrm{x}$ $10^{7} \mathrm{~m}^{3}$ to $0.6 \times 10^{7} \mathrm{~m}^{3}$ as the land-use changes over the years.

The change in storage follows the same trend and a total reduction of $0.13 \times 10^{7} \mathrm{~m}^{3}$ was observed between 1989 and 2039 land-use. But, considering the hydrologic soil conditions of the watershed that allowed more of infiltration and groundwater recharge, yet, the groundwater storage is decreasing, it indicates that land-use change have shaped the hydrology of Skudai watershed. It further elucidates the variability of the hydrological water balance of the watershed depends not only on the climatic conditions but also the land-use.

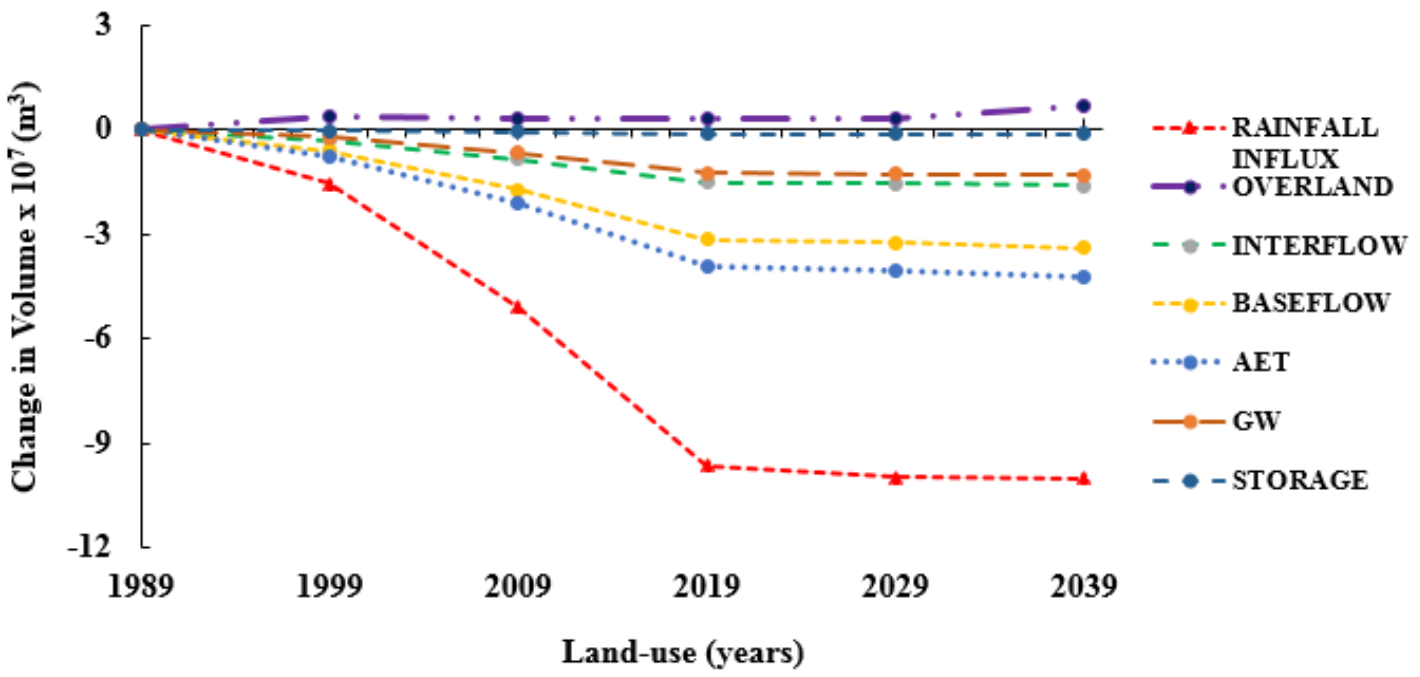

Figure 7 Change in volume due to land-use variability

Figure 7 illustrates the relative change in volume of the hydrological constituents due to land-use variation from 1989 to 2039. The negative values indicate decrease in volume and the positive values show increase in volume of the hydrological constituents. A sharp decrease was observed from 1989 to 2019. The reason for the steady drop in volume was that during those period, built-up areas were expanding across the entire watershed rather than consolidated at a particular location. But from 2019 to 2039, the built-up lands are expected to be controlled, instead of more expansion in other subbasin it will be consolidated within the existing urban areas due to the planned development restriction. Also, the spatial distribution of the water yield at subbasin scale for each temporal land-use shows an 
increase in water yield with increase urban development. While sub-basin with little or no changes in land-use between 1989 and 2039, the water yield remains unchanged. The spatial distribution of the water yield at sub-basin scale for each temporal land-use is shown in Figure 8. The result further affirms the impact of land-use changes on the water yield of a watershed system [45]. It was observed that the water yield increases with increase urban development (from maximum of $2.75 \mathrm{~mm} / \mathrm{yr}$ in 1989 to $3.12 \mathrm{~mm} / \mathrm{yr}$ in 2039).

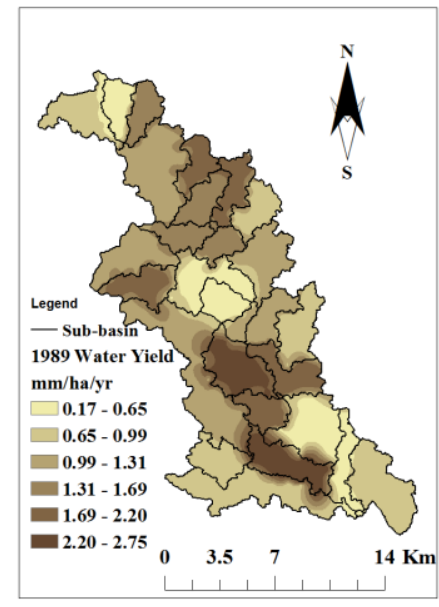

(a)

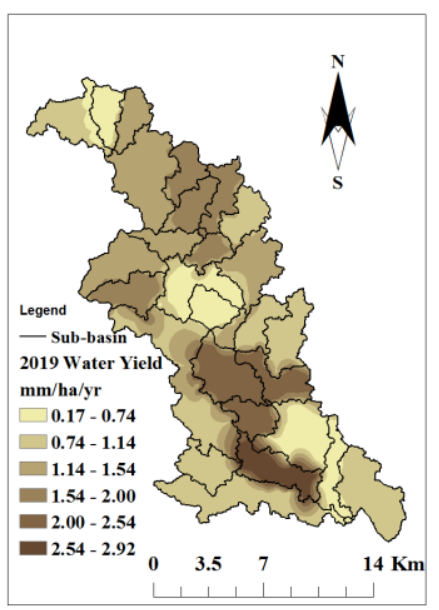

(d)

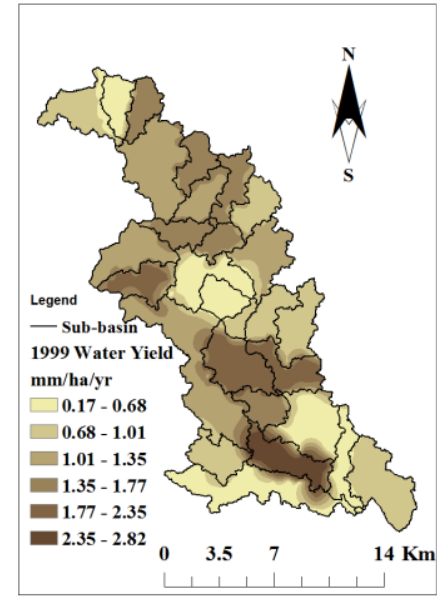

(b)

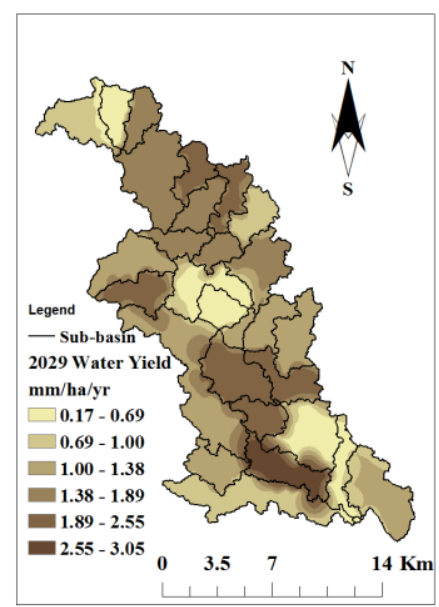

(e)

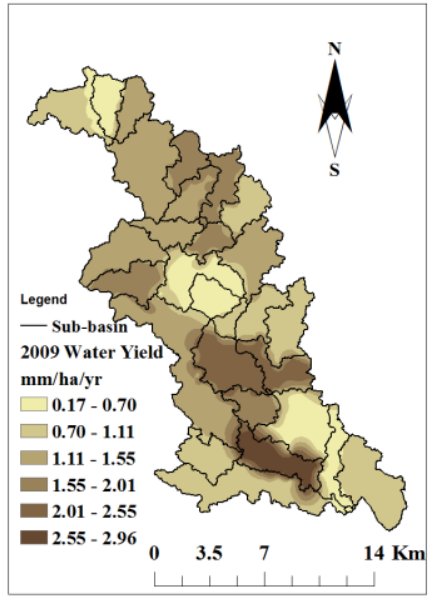

(c)

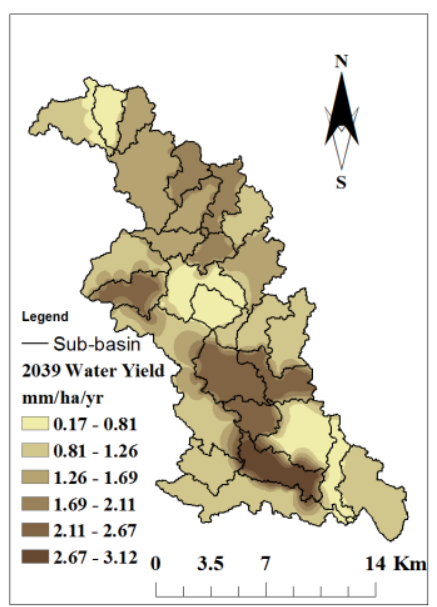

(f)

Figure 8 Distribution of Water Yield (mm/ha/yr) at sub-watershed scale (a) 1989 land-use (b) 1999 land-use(c) 2009 land-use (d) 2019 Land-use (e) 2029 Land-use (f) 2039 Land-use

\subsection{Simulated Flow with Temporal Land-use}

The average annual streamflow under different landuse conditions is shown in Table 7 . It shows an increase in the streamflows over the years (from 1989 to 2039). As the impervious land segment increases the surface runoff increases which lead to increased streamflow. Our results is similar to the studies conducted by Schilling et al. [46], that the average annual overland flow increased as water yield increased. In this study, the water yield increases from $3.84 \mathrm{~mm} / \mathrm{ha} / \mathrm{yr}$ in 1989 to $4.41 \mathrm{~mm} / \mathrm{ha} / \mathrm{yr}$ in 1999 and it shows a further increased as the land-use changes (Figure 8). The result also shows that an increase of $3.4 \%$ per annum of built-up area (refer to Table 2) will increase streamflow by $0.05 \mathrm{~m}^{3} / \mathrm{s}$. Also, as the watershed undulating terrain remain unaltered by urban development and being in a tropical region, the tendency for total runoff variability is eminent [47]. In relation to runoff values in Table 6 streamflows and total runoff are connected. At the hilltop, overland flow controls the streamflow, while at the valley interflow and baseflow control the streamflow because overland flow at the hilltop are converted to both interflow and baseflow before reaching the valley. As the effects of topographic changing is expected to alter the hydrological response of a watershed [47]. 
Table 7 Simulated average streamflow under different landuse condition

\begin{tabular}{ccccc}
\hline $\begin{array}{c}\text { spatiotempo } \\
\text { ral land-use } \\
\text { (year) }\end{array}$ & $\begin{array}{c}\text { Average } \\
\text { streamflo } \\
\mathbf{w}\left(\mathbf{m}^{3} / \mathbf{s}\right)\end{array}$ & $\begin{array}{c}\text { Chang } \\
\mathbf{e} \text { in } \\
\text { stream } \\
\text { flow } \\
\left(\mathbf{m}^{\mathbf{3}} / \mathbf{s}\right)\end{array}$ & $\begin{array}{c}\text { Percent } \\
\text { change } \\
\text { in } \\
\text { streamflo } \\
\mathbf{w}(\%)\end{array}$ & $\begin{array}{c}\text { Cumulati } \\
\text { ve } \\
\text { Increase } \\
\left(\mathbf{m}^{3} / \mathbf{s}\right)\end{array}$ \\
\hline 1989 & 9.32 & 0 & 0 & 0 \\
1999 & 10.20 & 0.88 & 9.44 & 0.88 \\
2009 & 10.59 & 0.39 & 3.85 & 1.27 \\
2019 & 10.89 & 0.30 & 2.86 & 1.58 \\
2029 & 11.29 & 0.40 & 3.64 & 1.97 \\
2039 & 11.54 & 0.24 & 2.17 & 2.22 \\
\hline
\end{tabular}

Also, the relative sensitivity of the hydrological elements due to land-use variability is evaluated, as illustrated in Figure 9a. AET shows high sensitivity to land-use change, followed by change in storage. Total runoff shows the lowest sensitivity for the four evaluated hydrological components. The low sensitivity of total runoff is attributed it tendency to shift from surface to subsurface zones based on the land-use category. Notably, an increased in the impervious segment will result to increase overland flow and decrease baseflow and interflow or vice visa. We further evaluate the sensitivity of the threecomponent runoff under the six land-use scenarios, and the result shows (Figure 9b) that baseflow and interflow are more sensitive to temporal land-use than overland flow. The increased in built-up land does not affect the topography and undulating nature of the watershed, therefore overland flow from hill top areas always discharge to the valleys and subsequently promote more baseflow and interflow than overland flow. Another contributing factor for low sensitivity of overland flow is the planned development that gives a provision of green areas and mixed land-use. Whereby, agricultural land, forest land (green areas) and built-up land are mixed-up within the watershed instead of concentrated urbanization.

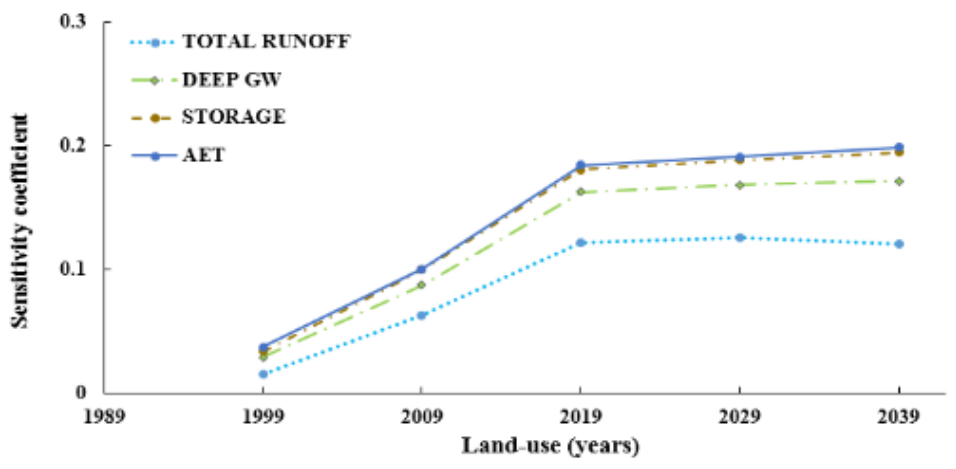

(a)

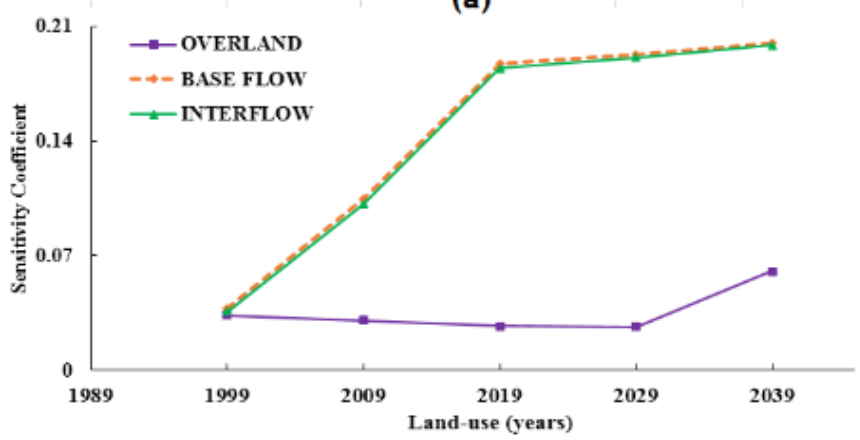

(b)

Figure 9 Relative Sensitivity of (a) Hydrological element to land-use (b) Runoff component to land-use

\subsection{CONCLUSION}

The hydrological changes of Skudai River watershed under different land-use conditions were evaluated using HSPF model. Remote sensing data was used to produce the historical land-use from 1989 to 2009, while land change model (LCM) was used to project the future land-use of the year 2019 to 2039. The landuse multi-date comparison shows that built-up area is the main driver of land-use changes while forest land decreases. Our findings show that total runoff is the primary sources of water loss in the watershed. Even though, the land-use have change over the years, the total runoff increases by only $2 \%$, indicating low response of the watershed to land-use changes. AET, groundwater, and change in storage decreases with increase built-up land, while the mean streamflows increases as the land-use change. Although the 
natural terrain of the watershed promotes more of surface runoff than groundwater recharge and change in storage, the sensitivity analysis of the hydrological elements under different temporal landuse shows that AET was more sensitive to land-use change, follows by change in storage and then groundwater (GW). Total runoff shows low sensitivity to land-use compare to AET and change in storage. But further sensitivity analysis of the runoff components reveals that baseflow and interflow were more sensitive to land-use change compare to overland flow.

This study shows that land-use of varied temporal scale can be used to estimate hydrological changes at a watershed scale and that physical disturbance of a watershed altered its hydrological cycle and water balance independent of climatic conditions. It was observed that, an annual increase of $3.39 \%$ of built-up land will increase streamflow by $0.05 \mathrm{~m}^{3} / \mathrm{s}$ and decreases AET, GW, and change in storage by $0.39 \%$, $0.34 \%$ and $0.38 \%$ respectively. This implies that integration of remote sensing techniques and GISbased models can provide an insightful information on the hydrological variability of a watershed that are useful for water resources planners and other decision makers.

\section{Acknowledgement}

This research was supported by Department of Irrigation and Drainage (DID) and Department of Environment (DOE) Malaysia

\section{References}

[1] Zhao, Y., Zhang, K., Fu, Y., Zhang, H. 2012. Examining Landuse/land-cover Change in the Lake Dianchi Watershed of the Yunnan-Guizhou Plateau of Southwest China with Remote Sensing and GIS Techniques: 1974-2008. International Journal of Environmental Research and Public Health. 9(11): 3843-3865. DOI:10.3390/ijerph9113843.

[2] Potter, T. D., Colman, B. R. 2003. Handbook of Weather Climate, and Water, 2-Book Set. John Wiley \& Sons.

[3] Wang, R., Kalin, L., Kuang, W., Tian, H. 2014. Individual and Combined Effects of Land Use/Cover and Climate Change on Wolf Bay Watershed Streamflow in Southern Alabama. Hydrological Processes. 28(22): 5530-5546. DOI: 10.1002/hyp.10057.

[4] Croke, B. F. W., Merritt, W. S., Jakeman, A. J. 2004. A Dynamic Model for Predicting Hydrologic Response to Land Cover Changes in Gauged and Ungauged Catchments. Journal of Hydrology. 291(1): 115-131. DOI: 10.1016/j.jhydrol.2003.12.012.

[5] Zare, M., Samani, A. A. N., Mohammady, M. 2016. The Impact of Land Use Change on Runoff Generation in an Urbanizing Watershed in the North of Iran. Environmental Earth Sciences. 75(18): 1279. DOI: 10.1007/s12665-016-60587

[6] Yin, J., He, F., Xiong, Y. J., Qiu, G. Y. 2017. Effects of Land Use/Land Cover and Climate Changes on Surface Runoff in A Semi-Humid and Semi-Arid Transition Zone in Northwest China. Hydrology and Earth System Sciences. 21 (1): 183-196. DOI: 10.5194/hess-21-183-2017.

[7] Fisher, D. S., Steiner, J. L., Endale, D. M., Stuedemann, J. A., Schomberg, H. H., Franzluebbers, A. J., Wilkinson, S. R. 2000.
The Relationship of Land Use Practices to Surface Water Quality in the Upper Oconee Watershed of Georgia. Forest Ecology and Management. 128(1): 39-48. DOI: 10.1016/S0378-1127(99)00270-4.

[8] Davie, T. 2008. Fundamentals of Hydrology. Taylor \& Francis.

[9] Sun, N., Yearsley, J., Baptiste, M., Cao, Q., Lettenmaier, D. P. Nijssen, B. 2016. A Spatially, Distributed Model for Assessment of the Effects of Changing Land Use and Climate on Urban Stream Quality. Hydrological Processes. 30(25): 4779-4798. DOI: 10.1002/hyp.10964.

[10] Teferi, E., Bewket, W., Uhlenbrook, S., Wenninger, J. 2013. Understanding Recent Land Use and Land Cover Dynamics in the Source Region of the Upper Blue Nile, Ethiopia: Spatially Explicit Statistical Modeling of Systematic Transitions. Agriculture, Ecosystems \& Environment. 165: 98117.DOI: 10.1016/j.agee.2012.11.007.

[11] Foley, J. A., Defries, R., Asner, G. P., Barford, C., Bonan, G. Carpenter, S. R., Chapin, F. S., Coe, M. T., Daily, G. C., Gibbs, H. K., Helkowski, J. H. 2005. Global Consequences of Land Use. Science. 309(5734): 570-574. DOI: 10.1126/science.11117.

[12] Gautam, A. P., Webb, E. L., Shivakoti, G. P., Zoebisch, M. A. 2003. Land Use Dynamics and Landscape Change Pattern in a Mountain Watershed in Nepal. Agriculture, Ecosystems \& Environment. 99(1): 83-96. DOI: 10.1016/S0167$8809(03) 00148-8$.

[13] Fathian, F., Dehghan, Z., Eslamian, S. 2016. Evaluating the Impact of Changes in Land Cover and Climate Variability on Streamflow Trends (Case Study: Eastern Sub-Basins of Lake Urmia, Iran). Int. J. Hydrology Science and Technology. 6(1): 1-26. DOI:10.1504/IJHST.2016.073881.

[14] Lin, Y. P., Hong, N. M., Wu, P. J., Wu, C. F., Verburg, P. H. 2007. Impacts of Land Use Change Scenarios on Hydrology and Land Use Patterns in the Wu-Tu Watershed in Northern Taiwan. Landscape and Urban Planning. 80(1): 111-126. DOI: $10.1016 /$ j. landurbplan.2006.06.007.

[15] Mango, L. M., Melesse, A. M., Mcclain, M. E., Gann, D. Setegn, S. G. 2011. Land Use and Climate Change Impacts on the Hydrology of the Upper Mara River Basin, Kenya: Results of a Modeling Study to Support Better Resource Management. Hydrology and Earth System Sciences. 15(7): 2245. DOI: 10.5194 /hess-15-2245-2011.

[16] Getachew, H. E., Melesse, A. M. 2012. The Impact of Land Use Change on the Hydrology of the Angereb Watershed, Ethiopia. International Journal of Water Sciences. 1. DOI: $10.5772 / 56266$

[17] Zheng, X. Q., Zhao, L., Xiang, W. N., Li, N., Lv, L. N., \& Yang, X. 2012. A Coupled Model for Simulating Spatio-Temporal Dynamics of Land-Use Change: A Case Study in Changqing, Jinan, China. Landscape and Urban Planning, 106(1): 51-61. DOI: 10.1016/J.LANDURBPLAN.2012.02.006.

[18] Wingate, V. R., Phinn, S. R., Kuhn, N., Bloemertz, L., \& Dhanjal-Adams, K. L. 2016. Mapping Decadal Land Cover Changes in the Woodlands of North Eastern Namibia from 1975 To 2014 Using the Landsat Satellite Archived Data. Remote Sensing. 8(8): 68. DOI: 10.3390/rs8080681.

[19] Yu, X. J., Ng, C. N. 2007. Spatial and Temporal Dynamics of Urban Sprawl Along Two Urban-Rural Transects: A Case Study of Guangzhou, China. Landscape and Urban Planning. 79(1): 96-109. DOI: 10.1016 /j. landurbplan.2006.03.008.

[20] Foody, G. M. 2002. Status of Land Cover Classification Accuracy Assessment. Remote Sensing of Environment. 80(1): 185-201. DOI: 10.1016/S0034-4257(01)00295-4.

[21] Jensen, J. R., Lulla, K. 2008. Introductory Digital Image Processing: A Remote Sensing Perspective. Geocarto International. 2(1): 65. DOI: 10.1080/10106048709354084.

[22] Hyandye, C., Martz, L. W. 2017. A Markovian and Cellular Automata Land-Use Change Predictive Model of the Usangu Catchment. International Journal of Remote Sensing. 38(1): 64-81. DOI: 10.1080/01431161.2016.1259675.

[23] Abuelaish, B., Olmedo, M. T. C. 2016. Scenario of Land Use and Land Cover Change in the Gaza Strip Using Remote 
Sensing and GIS Models. Arabian Journal of Geosciences. 9(4): 1-14. DOI: 10.1007/s12517-015-2292-7.

[24] Malone, R. W., Yagow, G., Baffaut, C., Gitau, M. W., QI, Z., Amatya, D. M., Parajuli, P. B. Bonta, J. V., Green, T. R. 2015. Parameterization Guidelines and Considerations for Hydrologic Models. Trans. ASABE. 58(6): 1681-1703. DOI $10.13031 /$ trans.58.10709.

[25] Daniel, E. B., Camp, J. V., Leboeuf, E. J., Penrod, J. R., Dobbins, J. P., Abkowitz, M. D. 2011.Watershed Modeling and Its Applications: A State-of-the-Art Review. The Open Hydrology Journal. 5(1). DOI: 10.2174/1874378101105010026.

[26] Diaz-Ramirez, J., Duan, Z., Mcanally, W., Martin, J. 2008. Sensitivity of the HSPF Model to Land Use/Land Cover Datasets. Journal of Coastal Research. 89-94. DOI: 10.2112/1551-5036-52.sp 1.89

[27] Diaz-Ramirez, J. N., Mcanally, W. H., Martin, J. L. 2011. Analysis of Hydrological Processes Applying the HSPF Model in Selected Watersheds in Alabama, Mississippi, and Puerto Rico. Applied Engineering in Agriculture. 27(6): 937-954. DOI: $10.13031 / 2013.40627$.

[28] AQUA TERRA CONSULTANTS. 2016. Available at<http://www.aquaterra.com/resources/downloads/HSPE XPplus.php> Access 15.11.2016.

[29] Kim, S. M., Benham, B. L., Brannan, K. M., Zeckoski, R. W. and Doherty, J. 2007. Comparison of Hydrologic Calibration of HSPF Using Automatic and Manual Methods. Water Resources Research. 43(1). DOI: 10.1029/2006WR004883.

[30] U.S. Environmental Protection Agency 2000, BASINS Technical Note 6: Estimating hydrology and hydraulic parameters for HSPF, EPA-823-R-00-012, Office of Water Washington, DC.

[31] Teegavarapu, R. S., Meskele, T., Pathak, C. S. 2012. Geospatial Grid-based Transformations of Precipitation Estimates Using Spatial Interpolation Methods. Computers \& Geosciences. 40: 28-39. DOI: 10.1016/j.cageo.2011.07.004.

[32] Lu, D., \& Weng, Q. 2006. Use of Impervious Surface in Urban Land-Use Classification. Remote Sensing of Environment. 102(1): 146-160. DOI: 10.1016/j.rse.2006.02.010.

[33] Coulter, L. L., Stow, D. A., Tsai, Y. H., Ibanez, N., Shih, H. C., Kerr A., ... \& Mensah, F. 2016. Classification and Assessment of Land Cover and Land Use Change In Southern Ghana Using Dense Stacks of Landsat 7 ETM+ Imagery. Remote Sensing of Environment. 184: 396-409. DOI: 10.1016/j.rse.2016.07.016.

[31] Camacho, V. V., Ruiz-Luna, A., \& Berlanga-Robles, A. C. 2016. Effects of Land Use Changes on Ecosystem Services Value Provided by Coastal Wetlands: Recent and Future Landscape Scenarios. J Coast Zone Manag. 19: 418. DOl: $0.4172 /$ jczm. 1000418

[32] Hamdy, O., Zhao, S., Salheen, M. A., \& Eid, Y. Y. 2017. Analyses the Driving Forces for Urban Growth by Using IDRISI® Selva Models Abouelreesh-Aswan as a Case Study. Int. J. Eng. Technol. 9: 226-232. DOI: 10.7763/IJET. 2017.V9.975.

[33] Mei, A., Manzo, C., Fontinovo, G., Bassani, C., Allegrini, A., \& Petracchini, F. 2016. Assessment of Land Cover Changes in Lampedusa Island (Italy) using Landsat TM and OLI Data. Journal of African Earth Sciences. 122: 15-24. DOI: 10.1016/j.jafrearsci.2015.05.014.

[34] Moriasi, D. N., Arnold, J. G., Van Liew, M. W., Bingner, R. L., Harmel, R. D., \& Veith, T. L. 2007. Model Evaluation Guidelines for Systematic Quantification of Accuracy in Watershed
Simulations. Trans. Asabe. 50(3): 885-900. DOI: $10.13031 / 2013.23153$

[35] Hayashi, S., Murakami, S., Watanabe, M., \& Bao-Hua, X. 2004 HSPF Simulation of Runoff and Sediment Loads in the Upper Changjiang River basin, China. Journal of Environmental Engineering. 130(7): 801-815. DOI: 10.1061/ ASCE-0733-93722004-130:7-801.

[36] Paramananthan, S. 1998. Malaysian Soil Taxonomy (Second Approximation): A Proposal for the Classification of Malaysian Soils. Malaysian Society of Soil Science. ISBN: 9679945200.

[37] Paramananthan, S. 2000. Soils of Malaysia: Their Characteristics and Identification, Volume 1. Academy of Sciences Malaysia. ISBN: 9839445065

[38] Mamedov, A. I., Levy, G. J., Shainberg, I., \& Letey, J. 2001 Wetting Rate, Sodicity, ad Soil Texture Effects on Infiltration Rate and Runoff. Soil Research. 39(6): 1293-1305. DOI: $10.1071 /$ SR01029.

[39] Zhou, F., Xu, Y., Chen, Y., Xu, C. Y., Gao, Y., \& Du, J. 2013. Hydrological Response to Urbanization at Different SpatioTemporal Scales Simulated by Coupling of CLUE-S and the SWAT Model in the Yangtze River Delta Region. Journal of Hydrology. 485: 113-125. DOI: 10.1016/j.jhydrol.2012.12.040.

[40[ Viola, M. R., Mello, C. R., Beskow, S., \& Norton, L. D. 2014 Impacts of Land-Use Changes on the Hydrology of the Grande River Basin Headwaters, Southeastern Brazil. Water Resources Management. 28(13): 4537-4550. DOI: 10.1007/s1 1269-014-07491 .

[41] Napoli, M., Massetti, L., \& Orlandini, S. 2017. Hydrological Response to Land Use and Climate Changes in a Rural Hilly Basin in Italy. CATENA. 157: 1-11. DOI: 10.1016/j.catena.2017.05.002

[42] Tang, G., Carroll, R. W., Lutz, A., \& Sun, L. 2016. Regulation of Precipitation-Associated Vegetation Dynamics on Catchment Water Balance in a Semiarid and Arid Mountainous Watershed. Ecohydrology. DOI: 10.1002/eco.1723.

[43] Mildrexler, D., Yang, Z., Cohen, W. B., \& Bell, D. M. 2016. A Forest Vulnerability Index Based on Drought and High Temperatures. Remote Sensing of Environment. 173: 314-325. DOl: 10.1016/j.rse.2015.11.024.

[44] Kundu, S., Khare, D., \& Mondal, A. 2017. Past, Present and Future Land Use Changes and Their Impact on Water Balance. Journal of Environmental Management. 197: 582-596. DOI: 10.1016/j.jenvman.2017.04.018.

[45] Schilling, K. E., Jha, M. K., Zhang, Y. K., Gassman, P. W., \& Wolter C. F. 2000. Impact of Land Use and Land Cover Change on the Water Balance of a Large Agricultural Watershed: Historical Effects and Future Directions. Water Resources Research. 44(7). DOI: 10.1029/2007WR006644.

[46] Valentin, C., Agus, F., Alamban, R., Boosaner, A., Bricquet, J. P., Chaplot, V. ... \& Phachomphonh, K. 2008. Runoff and Sediment Losses from 27 Upland Catchments in Southeast Asia: Impact of Rapid Land Use Changes and Conservation Practices. Agriculture, Ecosystems \& Environment. 128(4): 225-238. DOI: 10.1016/j.agee.2008.06.004

[47] Vivoni, E. R., Ivanov, V. Y., Bras, R. L., \& Entekhabi, D. 2005. On the Effects of Triangulated Terrain Resolution on Distributed Hydrologic Model Response. Hydrological Processes. 19(11): 2101-2122. DOI: 10.1002/hyp.5671. 